\title{
A háziorvos szerepe az acromegaliás betegek gondozásában, fókuszban a szénhidrát-anyagcsere
} zavara

\author{
Hargittay Csenge dr..$^{1}$ - Dénes Judit dr. ${ }^{2}$ - Hubina Erika dr. ${ }^{2}$ \\ Kovács Gábor László dr. ${ }^{3}$ - Görömbey Zoltán dr. ${ }^{2}$ - Czirják Sándor dr. ${ }^{4}$ \\ Kovács László dr. ${ }^{2}$ - Vörös Krisztián dr. ${ }^{1}$ - Góth Miklós dr. ${ }^{2}$ \\ ${ }^{1}$ Semmelweis Egyetem, Általános Orvostudományi Kar, Családorvosi Tanszék, Budapest \\ ${ }^{2}$ Magyar Honvédség Egészségügyi Központ, II. Belgyógyászati Osztály, Endokrinológia Szakprofil, Budapest \\ ${ }^{3}$ Pest Megyei Flór Ferenc Kórház, I. Belgyógyászati Osztály, Kistarcsa \\ ${ }^{4}$ Országos Klinikai Idegtudományi Intézet, Budapest
}

\begin{abstract}
Az acromegalia ritka, de klinikailag fontos betegség, amelyet a növekedési hormon és az inzulinszerü növekedési faktor-1 krónikusan magas szintje okoz. Számos tünete és komplikációja lehet, amelyek közül a diabetes mellitus gyakori szövődmény. A növekedési hormon különböző mechanizmusokon keresztül hathat a szénhidrát-anyagcserére és idézhet elő inzulinrezisztenciát. Cikkünkben egy acromegaliás beteg esetét dolgozzuk fel, kiemelve a beteg szénhidrátanyagcsere-eltéréseit, valamint az eset kapcsán ismertetjük az acromegalia kezelésében használt terápiás lehetőségeknek a glükózháztartásra gyakorolt hatását a nemzetközi irodalom áttekintésével. A contrainsularis hatású növekedésihormon-túlprodukció rontja a glükóztoleranciát. Ennek megfelelően a kórosan fokozott növekedésihormon-termelést csökkentő különböző kezelési módok (mint a sebészi vagy radioterápia, illetve a gyógyszeres kezelés bizonyos típusai) hatására javul a szénhidrát-anyagcsere. Ugyanakkor a gyógyszeres terápiás lehetőségek közül az első generációs szomatosztatinreceptor-ligandok az esetek kis részében ronthatják a szénhidrátháztartást, míg a második generációs pazireotid a betegek jelentős részénél hyperglykaemiát okoz. Az acromegaliás beteg kezelése komplex feladat, több diszciplína képviselői (endokrinológus, idegsebész, radioterapeuta, az egyes speciális problémák megoldásában részt vevő orvosok, fogorvosok) végzik, de a kezelés összefogásáért az endokrinológus szakorvos a felelős. Az acromegaliának, illetve a kezelés szövődményeinek, kiemelten a szénhidrátháztartás zavarainak ellátásában a háziorvosnak is fontos szerepe van, ehhez pedig ismernie kell a kezelési módozatok fóbb pontjait és potenciális mellékhatásait.
\end{abstract}

Orv Hetil. 2020; 161(40): 1724-1729.

Kulcsszavak: acromegalia kezelése, diabetes mellitus, szénhidrát-anyagcsere

\section{The role of the general practitioner in the care of acromegalic patients, with glucose metabolism dysfunction in the focus}

Acromegaly is a rare, but clinically important disease, caused by growth hormone and insulin-like growth factor 1
overproduction. Among the different symptoms and complications, diabetes mellitus is a substantial one. Through
different mechanisms, growth hormone affects glucose metabolism and causes insulin resistance. In this paper, we
present the medical history of an acromegalic patient, focusing on glucose metabolism abnormalities. We review the
effects of different therapeutic modalities used in the treatment of acromegaly on glucose homeostasis. The overpro-
duction of the contra-insulin growth hormone deteriorates glucose metabolism. Therefore, lowering pathologically
high growth hormone level by surgical, medical or radiotherapy improves glucose metabolism. On the other hand,
first generation somatostatin receptor ligands might worsen glucose homeostasis in some cases, while the second
generation somatostatin receptor ligand pasireotide causes hyperglycemia in the majority of patients. The treatment
of an acromegalic patient requires complex, interdisciplinary teamwork (endocrinologist, neurosurgeon, radiothera- 
pist and other specialists), led by endocrinologists. General practitioners play an important role in the treatment of acromegalic patients, especially in monitoring the complications of the disease, like glucose metabolism abnormalities. Therefore, they must be familiar with the different therapeutic options and their potential side effects.

Keywords: treatment of acromegaly, diabetes mellitus, glucose metabolism

Hargittay Cs, Dénes J, Hubina E, Kovács GL, Görömbey Z, Czirják S, Kovács L, Vörös K, Góth M. [The role of the general practitioner in the care of acromegalic patients, with glucose metabolism dysfunction in the focus]. Orv Hetil. 2020; 161(40): 1724-1729.

(Beérkezett: 2020. március 3.; elfogadva: 2020. április 17.)

\section{Rövidítések}

$\mathrm{BMI}=($ body mass index $)$ testtömegindex $; \mathrm{DPP} 4=($ dipeptidyl peptidase-4) dipeptidil-peptidáz-4; FFA = (free fatty acid $)$ szabad zsírsav; $\mathrm{GH}=$ (growth hormone) növekedési hormon; GLPl = (glucagon-like peptid-1) glükagonszerü peptid-1; $\mathrm{HbA}_{\mathrm{lc}}=$ hemoglobin- $\mathrm{A}_{\mathrm{lc}} ; \mathrm{IGFl}=($ insulin-like growth factor 1$)$ inzulinszerú növekedési faktor-1; LAR = (long-acting release $)$ hosszú hatású; $\mathrm{MRI}=$ (magnetic resonance imaging $)$ mágneses rezonanciás képalkotás; OGTT $=$ (oral glucose tolerance test $)$ orális glükóztolerancia-teszt; SGLT = (sodium-glucose linked transporter) nátrium-glükóz-kotranszporter; SRL = (somatostatin receptor ligand) szomatosztatinreceptor-ligand; SSTR = (somatostatin receptor) szomatosztatinreceptor; ULN = (upper limit of normal) a normális tartomány felső határa

Az acromegalia ritkán elóforduló betegség, újabb adatok szerint prevalenciája 125 beteg/1 millió lakos. Jelentősége nagy, mert a kezeletlen vagy nem megfelelően kezelt kórkép mortalitása fokozott. Szisztémás betegség, amelyet a növekedési hormon $(\mathrm{GH})$ és az inzulinszerú növekedési faktor-1 (IGFl) krónikusan magas szintje okoz. Szövődményei, különösen a cardiovascularis és légzőszervi komplikációk a kezeletlen betegek élethoszszát 10 évvel is megrövidíthetik. Az esetek 98\%-ában jóindulatú hypophysisadenoma okozza a GH-túltermelést. A maradék 2\% hátterében somatotrop hyperplasiát előidéző hypothalamicus vagy neuroendokrin ectopiás növekedési hormont termelő tumor vagy GH-termelő hypophysiscarcinoma áll. Ritkán különböző genetikai eltérések következménye az acromegalia [1].

Az acromegaliának számos tünete és szövődménye lehet, amelyek közül a szénhidrát-anyagcsere zavara az acromegalia gyakori komplikációja. A csökkent glükóztolerancia prevalenciája 35-40\%, a manifeszt cukorbetegségé pedig 15\% [1]. A glükózregulációs zavar kialakulására hajlamosít az emelkedett testtömegindex (BMI), az idősebb életkor, a magas IGFl-szint és a családi anamnézisben szereplő diabetes mellitus [2]. A szénhidrátanyagcsere-zavar hátterében álló fő patomechanizmus az inzulinrezisztencia. A GH a zsírszövetben fokozza a lipolízist, ezáltal nő a szabad zsírsavak (FFA-k) szintje. A magas FFA-szint a májban inzulinrezisztenciát okoz, fokozódik a glükoneogenezis és a glikogenolízis, nő az endogén glükóztermelés. Romlik az inzulindependens glükózfelvétel a perifériás szövetekben, és csökken a glükóz hasznosulása az izmokban és a zsírsejtekben. A kialakuló hyperglykaemia hatására a pancreasban fokozódik az inzulin termelése, hyperinsulinaemia alakul ki, amely idővel a béta-sejtek kimerüléséhez, 2-es típusú diabeteshez vezethet [3]. Emellett a növekedési hormon direkt gátló hatást is kifejt az inzulin által közvetített jelátviteli mechanizmusra, emiatt csökken a vázizomzat és a zsírszövet glükózfelvétele, ami súlyosbítja az inzulinrezisztenciát és a hyperglykaemiát [4].

Az acromegalia kezelésének célja egyrészt a biokémiai kontroll elérése (az IGFl-szint a nemnek, a kornak megfelelő normális tartományban, a GH-szint orális glükóztolerancia-teszt [OGTT] vagy GH-profil során $1 \mathrm{ng} / \mathrm{ml}$ alatt legyen), másrészt a tumor méretének csökkentése. A kezelés lehetőségei az idegsebészeti beavatkozás, a gyógyszeres kezelés és a radioterápia, valamint ezek kombinációi [5]. Sikeres kezelést követően, a kívánt hormonszintek elérése esetén, a halálozás az egészséges populáció mortalitási szintjére csökken. A kezelés végső célja a mortalitás csökkentése.

Az acromegalia gondozását endokrinológus szakorvos fogja össze, a betegség felismerésében és követésében azonban a háziorvosnak is fontos szerepe van. Gyakran a helyettesítő/ügyeletes háziorvos gondol rá először, akinek esetleg szembetűnőbbek a korábban nem ismert beteg acromegaloid vonásai. A háziorvos a tünetek mellett a meglévő társbetegségek okát kutatva is gondolhat acromegaliára. Fontos feladata ezeken kívül - az endokrinológus irányításával - a betegek követése, a szövődmények szûrése, a kezelések lehetséges mellékhatásainak ellenőrzése és a betegek támogatása.

\section{Esetismertetés}

A 43 éves férfi beteg kórtörténetében hypertonia, hyperlipidaemia, spondylarthrosis, steatosis hepatis, obesitas (BMI: $36,5 \mathrm{~kg} / \mathrm{m}^{2}$ [2005-ben $32,3 \mathrm{~kg} / \mathrm{m}^{2}$ ]) és struma nodosa szerepel. 2005-ben a krónikus fülzúgás és recidív külsőhallójárat-gyulladások miatt elvégzett koponyakomputertomográfia, majd mágneses rezonanciás képalkotó vizsgálatok (MRI-k) supra- és infrasellarisan terjedő 
óriás adenomát $(49 \times 25 \mathrm{~mm})$ igazoltak kezdődő hydrocephalussal. Az acromegalia gyanúját a biokémiai eredmények is alátámasztották, az OGTT során mért GHminimum 7,1 ng/ml volt, az IGFl-érték pedig $844 \mathrm{ng} /$ $\mathrm{ml}=2,3 \mathrm{ULN}$ (upper limit of normal). A hypophysismacroadenoma mütétje előtt a beteg egy éven át (a bromokriptin hatástalansága után) oktreotid-LAR- (longacting release) (kezdetben $10 \mathrm{mg} /$ hó, majd fokozatosan emelve az adagot $30 \mathrm{mg} /$ hó dózisig) kezelésben részesült az adenoma megkisebbítése és a klinikai tünetek enyhítése céljából. A nem megfelelő hatásosság miatt 2006. 09. 13-án transsphenoidalis behatolásból mútétet végeztek. A szövettan $\mathrm{GH} /$ prolaktin termelö somatotrop adenomát igazolt. A mütétet követően a betegnél centralis hypadrenia, hypothyreosis, hypogonadismus alakult ki. A posztoperatív MRI során jelentős méretú $(9 \times 21 \times 12 \mathrm{~mm})$ residualis adenomát írtak le. Az opus után, ahogy az 1 a ábrán is látható, a hormonális aktivitás átmenetileg csökkent. Később az ismételt IGFl-emelkedés és residualis adenoma miatt kért idegsebészeti konzílium során kezdetben mütétet még nem javasoltak, ezért $10 \mathrm{mg}$ oktreotid-LAR-kezelést indítottunk. A kontrollsella-MRI során a residualis képlet progresszióját (14 × $12 \times 24 \mathrm{~mm}$ ) írták le, ezért 2009. 11. 11-én jobb oldali superciliaris craniotomiás feltárásból reoperációra került sor. A mútét utáni MRI-n perzisztáló tumor $(15 \times 8,5 \times$ 9,6 mm) volt látható, és csak enyhe mérséklődés, majd ismételt emelkedés mutatkozott az IGFl értékében, ezért az acromegalia perzisztálását véleményeztük.
A bromokriptinkezelés hatástalanságát követően - korábban (részlegesen) hatásosnak bizonyult - oktreotidLAR-kezelést kezdtünk, 30 mg/hó dózisig feltitrálva. A nagy dózisú oktreotid-LAR-kezelés ellenére az acromegalia aktív maradt, így a további dózisemelés helyett az eltérő hatásmechanizmusú, GH-receptor-antagonista pegviszomanttal indítottunk $15 \mathrm{mg} / \mathrm{nap}$ kezelést. Az ajánlottnál magasabb kezdő dózist a magas GH- és IGF1-szintek indokolták. A 2017. januárban készült sella-MRI alapján a residualis adenomában nem írtak le változást. Az idegsebész ekkor nem újabb mútétet, hanem irradiációt javasolt. Neuroonkológus azonban csak akkor indikálta a sella frakcionált besugárzását, ha minden egyéb kezelés hatástalan volt. A beteg fiatal életkora és a lehetséges mellékhatások miatt egyelöre a pegviszomantterápiában dózisemelés történt, először 20, majd $30 \mathrm{mg} /$ nap dózisra. A maximálisan engedélyezett (30 $\mathrm{mg} / \mathrm{nap}$ ) kezelés ellenére is változatlanul magas IGFl-értékek miatt a betegnél a közelmúltban elérhetővé vált, szélesebb szomatosztatinreceptor (SSTR)-hatásspektrumú második generációs szomatosztatinreceptorligand (SRL) pazireotid-LAR $60 \mathrm{mg} /$ hó terápiát indítottunk. A megkezdett $60 \mathrm{mg} /$ hó kezelés hatására az acromegalia átmenetileg kontrollált volt, de az IGFl hamarosan ismét jelentősen emelkedett, továbbá a beteg szénhidrátháztartása is egyértelmüen romlott, ezért a kezelést módosítottuk: kisebb dózisú pazireotid (40 $\mathrm{mg}$ /hó) mellett heti három alkalommal $15 \mathrm{mg}$ pegviszomant kombinált kezelésre tértünk át (1. ábra).

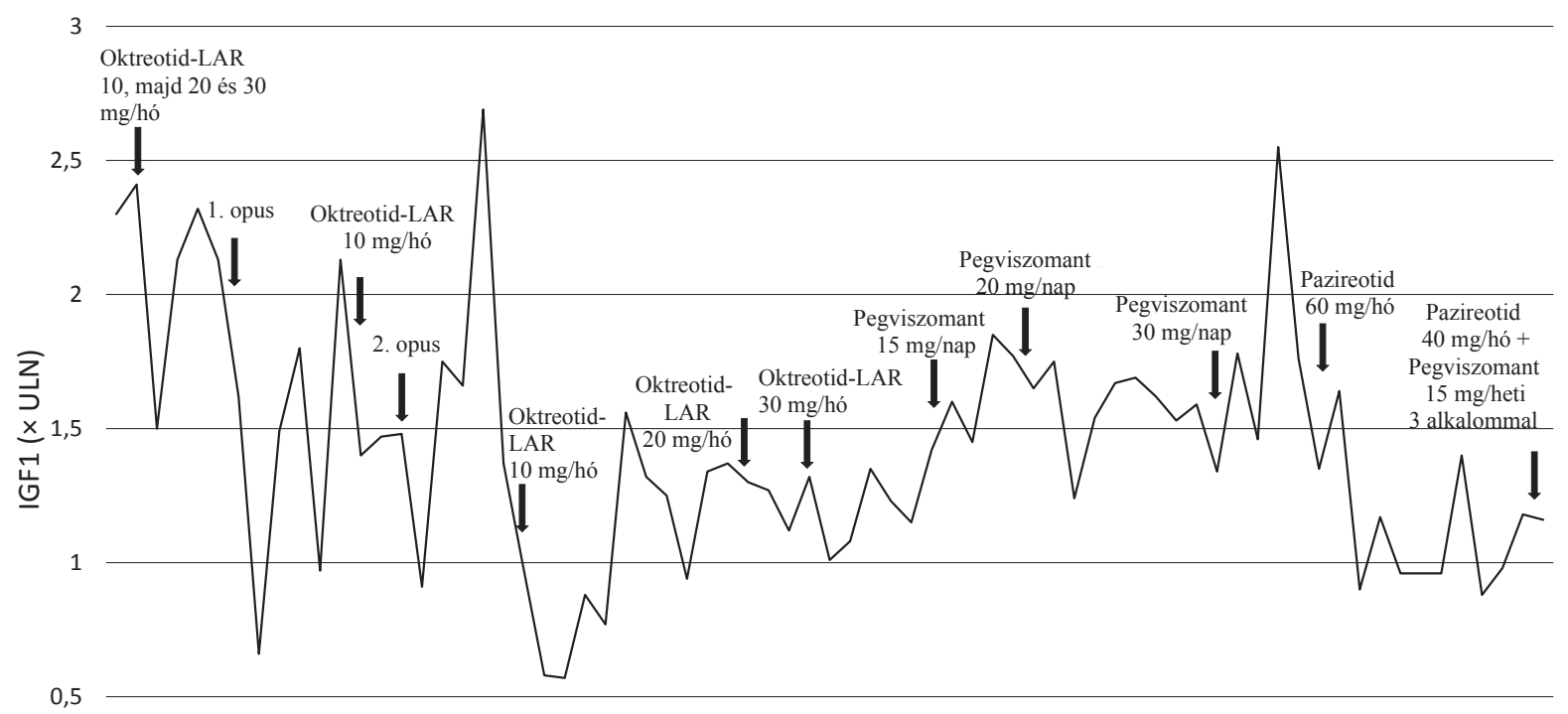

0

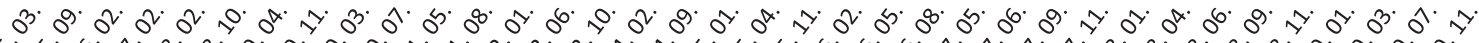

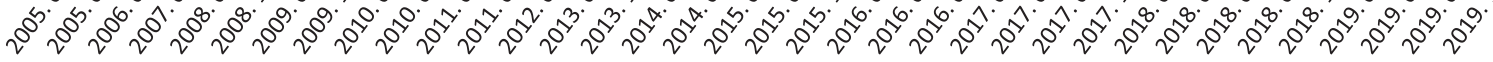

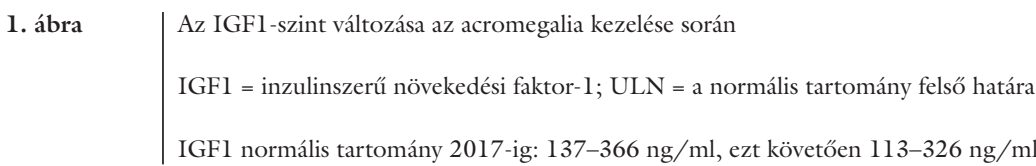


A beteg szénhidrátháztartása 10 éven keresztül egyensúlyban volt. Az acromegalia diagnózisakor végzett OGTT eredménye: vércukor: 0 . perc $6,0 \mathrm{mmol} / 1,120$. perc $5,5 \mathrm{mmol} / 1$. Ahogy a 2. ábrán látható, a beteg szénhidrátháztartása az oktreotid-LAR-kezelés alatt romlott, és 2015 áprilisában az aktív acromegalia és a nagy dózisú oktreotid-LAR-kezelés mellett szekunder cukorbetegséget diagnosztizáltunk. Ekkor metforminterápiát kezdtünk, amelyre a dózis fokozatos emelésével a beteg szénhidrátháztartása javult. Az acromegalia kezelésében is terápiaváltás történt: oktreotid-LAR-kezelésről pegviszomant adására tértünk át, a beteg hemoglobin- $\mathrm{A}_{\mathrm{lc}}\left(\mathrm{HbA}_{\mathrm{lc}}\right)$-értéke 6,8\%-ra csökkent. Később $\mathrm{HbA}_{1 \mathrm{c}}$-értékei 6,8\% és 7,6\% között ingadoztak. 2018 augusztusában, a pazireotidkezelés indításával romló szénhidrát-anyagcsere miatt az antidiabetikumterápiát dipeptidil-peptidáz-4 (DPP4)-gátlóval egészítettük ki, de miután a vércukorértékek nem csökkentek, inzulinterápiát indítottunk, majd nátrium-glükóz-kotranszporter (SGLT2)-gátlóval bővült a kezelés. A szénhidrát-anyagcsere további javulása érdekében kezelését glükagonszerü peptid-1 (GLPl) analógjával egészítettük ki; jelenleg kombinált metformin + SGLT2-gátló, valamint inzulin + GLPl-analóg készítményt kap a beteg, amely mellett $\mathrm{HbA}_{1 \mathrm{c}}$-értéke tovább csökkent (2. ábra).

A beteg követésében és a szövődmények szürésében részt vesz a háziorvos is. Rendszeresen ellenőrzi a vércukor- és a vérnyomásnaplót, és amennyiben szükséges, kompetenciájának megfelelően módosít a kezelésen. A beteg a gépjármúvezetői engedély meghosszabbítása miatt háziorvosánál az obstruktív alvási apnoe szindróma kockázatának felmérésére alkalmas kérdőív kitöltése során 13 pontos eredményt ért el, ezért az érvényes rendelkezés alapján alvásdiagnosztikai vizsgálatra került előjegyzésre.

\section{Megbeszélés}

A GH fent említett diabetogén hatásai mellett, az acromegalia kezelésében használt különböző eljárások és gyógyszerek eltérő hatást fejtenek ki a szénhidrát-anyagcserére. A következókben ezt szeretnénk ismertetni, de figyelembe kell venni, hogy bármelyik kezelésre létrejövő GH-szint-csökkenés hatására javulhat a glükózanyagcsere, a terápia szénhidrátháztartásra gyakorolt direkt hatásától függetlenül.

A sebészi kezelés különböző tanulmányok alapján az esetek jelentős részében javíthatja a szénhidrát-anyagcserét, a radioterápiával kapcsolatban pedig még kevés vizsgálat született. Fontos azonban megemlíteni, hogy az opus (a besugárzáshoz hasonlóan) előidézhet részleges vagy esetleg teljes hypopituitarismust, amely eltérést okozhat a szénhidrát-anyagcserében [6].

Egy lengyel vizsgálatban szignifikáns csökkenést találtak az éhomi és az OGTT-vel mért plazmaglükózszintekben a mútét előtti értékekhez képest. A mütétet követően javult az inzulinérzékenység és a károsodott glükózmetabolizmus is [7]. Egy másik vizsgálat alapján abban az esetben, ha korábban károsodott a béta-sejtek múködése, a károsodott glükózmetabolizmus perzisztált
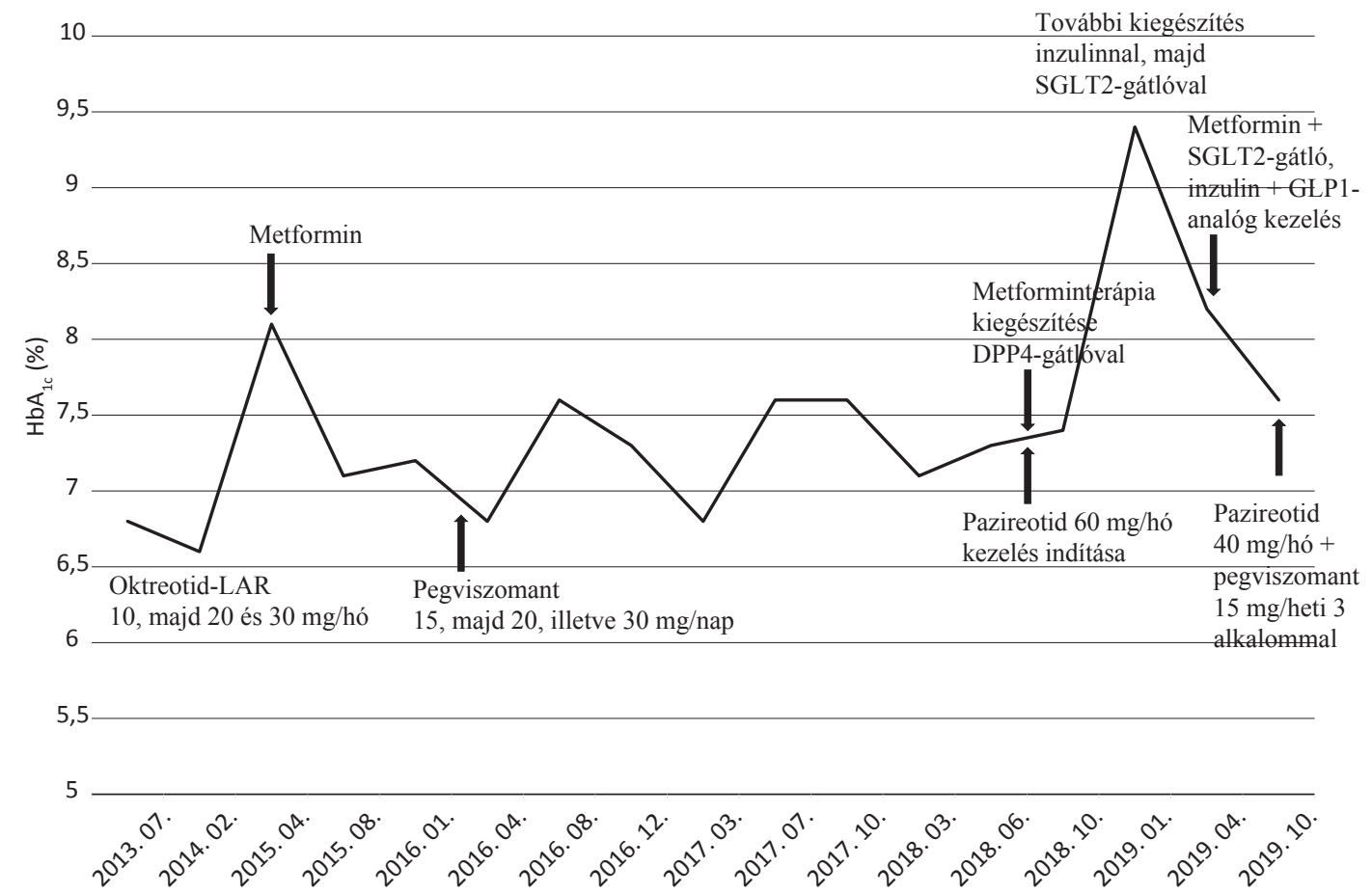

\begin{tabular}{l|l} 
2. ábra & $\begin{array}{l}A \mathrm{HbA}_{1 \mathrm{c}} \text {-értékek változása az acromegalia kezelése során } \\
\mathrm{HbA}_{\mathrm{lc}}=\text { hemoglobin- } \mathrm{A}_{\mathrm{lc}}\end{array}$
\end{tabular} 
az acromegalia sebészi kezelése (GH/IGFl normalizálódása) után is [8].

A gyógyszerek közül a dopaminagonisták valószínúleg a perifériás és a splanchnicus területek glükózfelvételének fokozásával és a májban a glükoneogenezis csökkentésével javítják a glükózanyagcserét $[9,10]$. A bromokriptin mérsékelten javítja a glükóztoleranciát acromegaliás betegekben [11]. Fontos megemlíteni, hogy a bromokriptin egyéb indikációs körben történő alkalmazására, a 2-es típusú diabetes bromokriptinnel történő kezelésére vizsgálatok történtek, és az amerikai Gyógyszer- és Élelmiszer-ellenőrző Hatóság már engedélyezte ez irányú felhasználását [12].

A SRL-ok a SSTR-ok aktiválásával gátolják a GH-szekréciót és a szomatotrop sejtek proliferációját. Öt különböző SSTR-altípus ismert. A GH-t szekretáló adenomák a SSTR 4-es altípusán kívül az összes receptort expreszszálják. Ismert, hogy a szomatosztatin az inzulinszekréciót a SSTR2, SSTR5 receptorokon keresztül gátolja, a glükagonszekréciót pedig a SSTR2-n keresztül. A SRLok közül az oktreotid és a lanreotid nagy affinitással kötődik a SSTR2-höz, és kisebb aktivitással a SSTR5-höz, ezáltal kevésbé borul fel az inzulin/glükagon egyensúly. A pazireotid a SSTR4 kivételével az összes SSTR-hoz nagy affinitással kötődik, elsősorban a SSTR5-ön hat. Erősebben gátolja az inzulinszekréciót, mint a glükagonszekréciót, ezért kifejezettebben hyperglykaemiát elóidéző hatású [3]. Számos vizsgálatban foglalkoztak a SRL-kezelés szénhidrátháztartásra gyakorolt hatásával acromegaliás betegeknél, ellentmondásos eredményekkel [4]. Egy, 31 vizsgálatot $(n=619)$ feldolgozó metaanalízisben, amelyben az oktreotid-LAR és a lanreotid autogél szénhidrát-metabolizmusra gyakorolt hatásait vizsgálták, mind az oktreotid, mind a lanreotid szignifikánsan csökkentette az éhomi inzulinértéket. Ez a hatás viszont öszszességében csekélynek bizonyult a glükózhomeosztázisra. Nem változtak szignifikánsan az éhomi vércukor és a $\mathrm{HbA}_{\mathrm{lc}}$ értékei, különösen akkor, amikor az acromegalia biokémiailag kontrollált volt [13]. A SRL-ok a GH/ IGFl szintek csökkentése által javítják az inzulinrezisztenciát, így a szénhidrátháztartást, ugyanakkor az inzulinszekréciót gátló hatásuk révén diabetogének. Összességében tehát az első generációs SRL-ok kismértékben rontják a szénhidrátháztartást, ezért a terápia alatt a vércukorszintet rendszeresen ellenőrizni kell.

A második generációs SRL pazireotid egészséges férfi önkénteseken végzett vizsgálat eredményei alapján gátolja az inzulin és az inkretinek szekrécióját, kevésbé gátolja a glükagonszekréciót, és nem hat a máj és a perifériás szövetek inzulinérzékenységére [14]. A pazireotid oktreotiddal szembeni jobb hatékonyságát és hyperglykaemiát előidéző hatását bizonyítja egy prospektív vizsgálat, amely alapján az oktreotiddal kezelteknél szignifikánsan több, pazireotiddal kezelt acromegaliás beteg érte el a biokémiai kontrollt 12 hónap alatt $(31,3 \%$ vs. $19,2 \%, p=0,007)$. A mellékhatásprofilt vizsgálva, gyakoribb volt a hyperglykaemia és a diabetes mellitus előfor- dulása a pazireotiddal kezelt csoportban, mint az oktreotiddal kezeltek körében $(28,7 \%$ és $19,1 \%$ vs. $8,3 \%$ és $3,9 \%)$ [15].

A másodvonalbeli kezelésként alkalmazott GH-receptor-antagonista pegviszomantnak kedvezőbbek a hatásai a szénhidrátháztartásra, mint a SRL-oknak. Csökkenti az éjszakai endogén glükóztermelést, javítja az inzulinérzékenységet, és csökkenti az éjszakai FFA-szintet [16]. Egy retrospektív vizsgálatban a SRL-oknak (oktreotid-LAR, lanreotid autogél), a pegviszomantnak és a kettó kombinációjának hatását vizsgálták a szénhidrátháztartásra. Az inzulinrezisztencia mindegyik gyógyszeres kezelésre javult, amennyiben az acromegalia kontrollálttá vált. Mind az éhomi, mind az OGTT során mért vércukorértékek magasabbak voltak a SRL-dal kezelt csoportban, csökkenő tendenciát mutattak a SRL + pegviszomant kombinációt kapó betegcsoportban, míg a legjobb értékeket azok a betegek érték el, akik csak pegviszomantkezelésben részesültek [17]. A pegviszomant szénhidrátháztartásra gyakorolt kedvező hatása miatt az acromegalia kezelésére vonatkozó 2018-as ajánlásba bekerült a gyógyszer választásának indikációi közé a szénhidrát-anyagcsere zavara [18].

A fentiek alapján és a beteg eredményeiből láthatjuk, hogy egyfelől komplex feladat az acromegalia kezelése, másfelől pedig a kezelésben alkalmazott különböző gyógyszereknek és kezelési módoknak sokrétü hatásaik lehetnek a szénhidrátháztartásra. Az acromegaliás betegek cukorbetegségének kezelésére nincs specifikus irányelv, a 2-es típusú diabetes mellitus kezelésére vonatkozó ajánlások az irányadók [19]. Bármelyik antidiabetikum használható, figyelembe véve az inzulinrezisztenciát is. Az első vonalban a metformin választandó, mert csökkenti a glükoneogenezist és az inzulinrezisztenciát $[20,21]$. A másodvonalbeli kezelés során a pazireotid által okozott hyperglykaemiában az inkretinhatású szerek (DPP4-gátlók, GLPl-receptor-agonisták) használata lehet előnyös, mert ellensúlyozzák az inkretinszintet csökkentő hatást [22]. Az inzulinterápia akkor válhat szükségessé, ha a hosszú időn keresztül fennálló GH-túlsúly miatt a bétasejtek károsodtak, illetve amikor a terápia mellékhatása miatt cukorbetegség alakul ki (pazireotid által okozott diabetes). Egy közelmúltban megjelent összefoglaló közlemény támpontot nyújt a pazireotid indukálta hyperglykaemia kezelésére, amely alapján a kezelés megkezdésétől kezdve végig szoros kontroll javasolt, valamint szükség esetén a DPP4-gátló-kezelés mihamarabbi indítása, hatástalanság esetén GLPl-receptor-agonistára, végül pedig a már említett inzulinkezelésre történő váltás [23].

\section{Következtetés}

Az acromegalia és annak kezelése a szénhidrátháztartásban jelentős változásokat idéz elő. A GH az izulinrezisztencia fokozásán keresztül rontja a glükózanyagcserét. A sikeres kezelés (mútéti, gyógyszeres, radioterápia) hatására csökken a GH-szint, ezáltal csökken az inzulinre- 
zisztencia, és javul a glükózháztartás. A sikeres sebészi kezelés, a dopaminagonisták és a növekedésihormonreceptor-antagonista pegviszomant javítják, az elsô generációs SRL-ok kismértékben rontják, a második generációs pazireotid pedig kifejezetten rontja a szénhidrát-anyagcserét.

A háziorvosnak fontos szerepe van az acromegaliának és az annak kezelése során észlelt szénhidrátháztartásnak az ellenőrzésében, kezelésében, továbbá a kórkép egyéb szövődményeinek, társbetegségeinek (kardiális tünetek, magas vérnyomás, zsír- és ásványianyagcsere-zavarok, légzőszervi megbetegedések) ellenőrzésében, kezelésében és nem utolsósorban az alvási apnoe szindróma szúrésében a gépjármúvezetői engedély megszerzésekor és meghosszabbításakor [24].

Anyagi támogatás: A tanulmány elkészítése anyagi támogatásban nem részesült.

Szerzői munkamegosztás: H. Cs.: Irodalomkutatás, az eset feldolgozása, a kézirat megszövegezése. D. J.: A kézirat megszövegezése. D. J., G. M., H. E., K. G. L., G. Z., K. L.: A beteg kezelésében részt vevő orvosok. Cz. S.: A beteget operáló idegsebész. V. K.: Az adatok megjelenítése ábrákon, a kézirat megszövegezése. G. M.: A kézirat véleményezése. A cikk végleges változatát valamennyi szerző elolvasta és jóváhagyta.

Érdekeltségek: A szerzőknek nincsenek érdekeltségeik.

\section{Irodalom}

[1] Góth M, Korbonits M. Acromegaly. In: Leövey A, Nagy VE, Paragh Gy, et al. (eds.) Handbook of endocrine and metabolic diseases. [Acromegalia. In: Leövey A, Nagy VE, Paragh Gy, et al. (szerk.) Az endokrin és anyagcsere-betegségek gyakorlati kézikönyve.] Medicina Könyvkiadó, Budapest, 2016; pp. 73-96. [Hungarian]

[2] Alexopoulou O, Bex M, Kamenicky P, et al. Prevalence and risk factors of impaired glucose tolerance and diabetes mellitus at diagnosis of acromegaly: a study in 148 patients. Pituitary 2014; 17: 81-89.

[3] Pivonello R, Auriemma RS, Grasso LF, et al. Complications of acromegaly: cardiovascular, respiratory and metabolic comorbidities. Pituitary 2017; 20: 46-62.

[4] Baroni MG, Giorgino F, Pezzino V, et al. Italian Society for the Study of Diabetes (SID)/Italian Endocrinological Society (SIE) guidelines on the treatment of hyperglycemia in Cushing's syndrome and acromegaly. J Endocrinol Invest. 2016; 39: 235-255.

[5] Dénes J, Korbonits M, Hubina E, et al. Treatment of acromega ly. [Az acromegalia kezelése.] Orv Hetil. 2010; 151: 1384-1393. [Hungarian]

[6] Verhelst J, Mattsson AF, Luger A, et al. Prevalence and characteristics of the metabolic syndrome in 2479 hypopituitary patients with adult-onset GH deficiency before GH replacement: a KIMS analysis. Eur J Endocrinol. 2011; 165: 881-889.

[7] Stelmachowska-Banaś M, Zieliński G, Zdunowski P, et al. The impact of transsphenoidal surgery on glucose homeostasis and insulin resistance in acromegaly. Neurol Neurochir Pol. 2011; 45: 328-334.
[8] Kinoshita Y, Fujii H, Takeshita A, et al. Impaired glucose metabolism in Japanese patients with acromegaly is restored after successful pituitary surgery if pancreatic beta-cell function is preserved. Eur J Endocrinol. 2011; 164: 467-473.

[9] Pijl H, Ohashi S, Matsuda M, et al. Bromocriptine: a novel approach to the treatment of type 2 diabetes. Diabetes Care 2000; 23: 1154-1161.

[10] Bahar A, Kashi Z, Daneshpour E, et al. Effects of cabergoline on blood glucose levels in type 2 diabetic patients: a double-blind controlled clinical trial. Medicine (Baltimore) 2016; 95: e4818.

[11] Rau H, Althoff PH, Schmidt K, et al. Bromocriptine treatment over 12 years in acromegaly: effect on glucose tolerance and insulin secretion. Clin Investig. 1993; 71: 372-378.

[12] Lopez Vicchi F, Luque GM, Brie B, et al. Dopaminergic drugs in type 2 diabetes and glucose homeostasis. Pharmacol Res. 2016; 109: 74-80.

[13] Mazziotti G, Floriani I, Bonadonna S, et al. Effects of somatostatin analogs on glucose homeostasis: a metaanalysis of acromegaly studies. J Clin Endocrinol Metab. 2009; 94: 1500-1508.

[14] Henry RR, Ciaraldi TP, Armstrong D, et al. Hyperglycemia associated with pasireotide: results from a mechanistic study in healthy volunteers. J Clin Endocrinol Metab. 2013; 98: 34463453

[15] Colao A, Bronstein MD, Freda P, et al. Pasireotide versus octreotide in acromegaly: a head-to-head superiority study. J Clin Endocrinol Metab. 2014; 99: 791-799.

[16] Higham CE, Rowles S, Russell-Jones D, et al. Pegvisomant improves insulin sensitivity and reduces overnight free fatty acid concentrations in patients with acromegaly. J Clin Endocrinol Metab. 2009; 94: 2459-2463.

[17] Urbani C, Sardella C, Calevro A, et al. Effects of medical therapies for acromegaly on glucose metabolism. Eur J Endocrinol. 2013; 169: 99-108.

[18] Melmed S, Bronstein MD, Chanson P, et al. A consensus statement on acromegaly therapeutic outcomes. Nat Rev Endocrinol. 2018; 14: 552-561.

[19] Hannon AM, Thompson CJ, Sherlock M. Diabetes in patients with acromegaly. Curr Diab Rep. 2017; 17: 8 .

[20] Jermendy Gy. (ed.) Clinical Practice Guideline - Diagnosis, antihyperglycaemic treatment and care of patients with diabetes in adulthood. [Egészségügyi szakmai irányelv - A diabetes mellitus kórismézéséről, a cukorbetegek antihyperglykaemiás kezeléséről és gondozásáról felnőttkorban.] Diabet Hung. 2017; 25: 3-77. [Hungarian]

[21] Torzsa P, Oláh I, Hargittay Cs, et al. Type 2 diabetes: what is the role of a general practitioner in the treatment of diabetes? [2-es típusú cukorbetegség: milyen szerepe van a családorvosnak a betegség kezelésében?] Lege Art Med. 2018; 28: 533-540. [Hungarian]

[22] Breitschaft A, Hu K, Hermosillo Reséndiz K, et al. Management of hyperglycemia associated with pasireotide (SOM230): healthy volunteer study. Diabetes Res Clin Pract. 2014; 103: 458-465.

[23] Coopmans EC, Muhammad A, van der Lely AJ, et al. How to position pasireotide LAR treatment in acromegaly. J Clin Endocrinol Metab. 2019; 104: 1978-1988.

[24] Szakács Z, Ádám Á, Annus JK, et al. Hungarian Society for Sleep Medicine guideline for detecting drivers with obstructive sleep apnea syndrome. [A Magyar Alvásdiagnosztikai és Terápiás Társaság módszertani ajánlása a közúti jármúvezetők egészségi alkalmasságának vizsgálatához az obstruktív alvási apnoe szindróma vonatkozásában.] Orv Hetil. 2016; 157: 892-900. [Hungarian]

(Hargittay Csenge dr., Budapest, Pf. 2, 1428 e-mail: hargittay.csenge@med.semmelweis-univ.hu) 